\title{
AKIBAT HUKUM PEMBATALAN AKTA JUAL BELI (AJB) ATAS TANAH OLEH PEJABAT PEMBUAT AKTA TANAH (PPAT) DALAM PUTUSAN MAHKAMAH AGUNG NOMOR 888/K/PDT/2016
}

\author{
Livia Clarista \\ (Mahasiswi Program S1 Fakultas Hukum Universitas Tarumanagara) \\ (E-mail: livia.clarista@yahoo.com)
}

\section{Endang Pandamdari}

(Corresponding Author)

(Dosen Hukum Jaminan Fakultas Hukum Universitas Tarumanagara. Meraih

Sarjana Hukum pada Fakultas Hukum Universitas Indonesia (1983), Spesialis

Notaris pada Fakultas Hukum Universitas Indonesia (1993), Magister Hukum

pada Fakultas Hukum Universitas Indonesia (1996), Doktor (Dr.) pada Fakultas

Hukum Universitas Trisakti (2011))

(E-mail: epandamdari@yahoo.com)

\begin{abstract}
Buying and selling is a process of transferring rights of land carried out by making a sale and purchase deed by a land deed official. Therefore, the procedure must be in accordance with the applicable laws and regulations to produce a valid deed and can be used to transfer the land rights. In this case, there was a mismatch in the procedure for making land sale and purchase deeds carried out by land deed official. This caused a legal defect in the deed which was then supported by a statement from the District Court Verdict Number 381/Pdt.G/2014/PN/Bdg. and the Bandung High Court with Decision Verdict 451/PDT/2015/ PT BDG., where both of them grant the plaintiff's claim, namely land deed official itself. However, the Supreme Court Judges considered that land deed official did not have a legal standing in filing a claim because it was deemed not to have legal interests in the sale and purchase deed. The Supreme Court Judges in Verdict Number 888 / PDT / 2016 canceled the previous court decision. This resulted in the deed returning to its original state. However, the deed can then only be canceled by the parties in it, but the cancellation also can only be done if both parties agree. While the legal consequences of the land deed official issuing the sale and purchase deed are the acceptance of sanctions in the form of temporary and permanent dismissals.
\end{abstract}

Keywords: Deed of sale and purchase, cancellation, land deed official 


\section{PENDAHULUAN}

\section{A. Latar Belakang}

Manusia pada hakikatnya adalah makhluk sosial dalam masyarakat suatu negara, yang akan selalu berinteraksi antara satu individu dengan yang lainnya. Berdasarkan hal tersebut, dapat dikatakan bahwa hubungan antar manusia tersebut menjadi suatu kebutuhan dasar. Hubungan antar individu dapat melahirkan banyak hal, salah satunya adalah perikatan, yang kemudian dapat menghasilkan apa yang dikenal dengan perjanjian. Perjanjian terdiri dari bermacam-macam jenis, salah satunya yang paling sering dijumpai di masyarakat adalah perjanjian jual beli. Menurut Pasal 1457 KUHPer, jual beli adalah suatu persetujuan dengan mana pihak yang satu mengikatkan dirinya untuk menyerahkan suatu barang, dan pihak yang lain untuk membayar harga yang dijanjikan. Jual beli pun terdiri dari banyak jenisnya, namun salah satu kegiatan jual beli yang cukup mendominasi dalam kehidupan bermasyarakat adalah jual-beli tanah.

Sejak dahulu, tanah sudah menjadi suatu kebutuhan dasar yang dibutuhkan oleh manusia dan hubungannya dengan pelaksanaan aktivitas sehari-hari manusia sangatlah erat. Hal tersebut kemudian mendorong manusia untuk melakukan berbagai usaha untuk dapat menguasai bidang tanah tertentu untuk dapat memaksimalkan penggunaannya.

Dengan adanya hak-hak atas tanah, telah memberikan wewenang kepada individu untuk mempergunakan tanah itu untuk kepentingan yang langsung berhubungan dengan penggunaan tanah. ${ }^{1)}$ Dialihkan hak artinya adanya pemindahan hak milik atas tanah dari pemiliknya kepada pihak lain dikarenakan adanya suatu perbuatan hukum. Contoh perbuatan hukum yaitu jual beli, tukar-menukar, hibah, penyertaan (pemasukan) dalam modal perusahaan, lelang. ${ }^{2)}$ Akta yang dibuat oleh dan di hadapan Pejabat Pembuat Akta Tanah (PPAT) menjadi suatu alat pembuktian telah terjadinya jual-beli

\footnotetext{
${ }^{1)}$ C.S.T Kansil, Pengantar Ilmu Hukum dan Tata Hukum Indonesia, (Jakarta: Balai Pustaka, 2002), hal.320.

${ }^{2)}$ Urip Santoso, Hukum Agraria Kajian Komprehensif, (Jakarta: Kencana Prenada Media Group, 2012), hal.94.
} 
dalam rangka pendaftaran pemindahan hak. ${ }^{3)}$ Akta yang disebut dengan Akta Jual Beli (AJB) berguna untuk menjamin hak dan kewajiban para pihak dan untuk menghindari adanya permasalahan mengenai hak atas tanah di kemudian hari dan digunakan sebagai pembuktian oleh para pihak yang ada di dalam perjanjian bahwa telah terjadinya perikatan dalam bentuk jualbeli. Penandatanganan dan pembuatan Akta Jual Beli menjadi suatu hal yang esensial dan wajib dilakukan dalam proses jual beli tanah karena pada saat itu pula hak-hak atas tanah beralih dari satu pihak kepada pihak lainnya. Akta yang diterbitkan PPAT menganut asas dokumentatif. Yang dimaksudkan dengan asas dokumentatif adalah bahwa sebahagian besar transaksi dan pembuktian hak atas tanah dilakukan dengan dokumentasi tertulis. ${ }^{4)}$ Oleh karena itu, PPAT selaku pejabat umum yang mempunyai kewenanngan dalam pembuatan akta tanah harus memiliki ketelitian dan kemampuan yang memadai agar akta-akta yang dibuatnya tidak menimbulkan permasalahan di kemudian hari bagi para pihak yang bersangkutan.

Namun, pada prakteknya tidak sedikit pembuatan akta jual beli yang dilakukan tidak selaras dengan hukum positif yang berlaku, khususnya dengan Peraturan Pemerintah Nomor 24 Tahun 1997 tentang Pendaftaran Tanah. Hal tersebut meyebabkan banyaknya problema yang timbul di dalam masyarakat mengenai akta jual beli yang kemudian menimbulkan akibat hukum bagi para individu yang membuatnya. Namun, tidak sedikit pula kesalahan tersebut terletak pada PPAT sendiri. Sudah merupakan suatu kewajiban bagi PPAT untuk mengikuti seluruh ketentuan hukum positif yang berlaku di Indonesia guna menghindari adanya kesalahan dalam penerbitan akta. Apabila dalam pembuatan akta-aktanya seorang PPAT kurang cermat atau lalai maka akan dapat menimbulkan kerugian pada para pihak, baik pada pihak yang melakukan perbuatan hukum itu sendiri

\footnotetext{
${ }^{3)}$ Urip Santoso, Pendaftaran dan Peralihan Hak Atas Tanah, Cetakan ke-9, (Jakarta: Kencana Prenada Media Group, 2013), hal.369.

4) Munir Fuady, Konsep Hukum Perdata, Cetakan ke-2, (Jakarta: Rajawali Pers, 2015), hal.47.
} 
maupun pada pihak terkait lainnya. Para pihak dapat menutut ganti rugi berdasarkan hukum perdata yang berlaku.

Ketidakhati-hatian tersebut dapat terjadi dalam hal tidak terpenuhinya persyaratan di antara para pihak sehingga menyebabkan terjadinya ketidaksesuaian dengan ketentuan hukum yang ada. Perbuatan ini pun dapat menyebabkan pembatalan akta di kemudian oleh dari para pihak yang bersangkutan dalam perjanjian tersebut. Pembatalan akta tersebut kemudian akan berdampak hukum kepada pihak-pihak yang ada di dalamnya. Oleh karena itu hal tersebut kemudian menarik perhatian penulis dalam menyusun jurnal ini.

Kasus yang dipakai penulis sebagai studi kasus pada jurnal ini, yaitu Putusan Mahkamah Agung Nomor 888/K/Pdt/2016, dimana seorang PPAT di Bandung yang bernama Rian Pratama, S.H., M.Kn. mengajukan pembatalan terhadap akta jual beli yang dibuatnya akibat adanya ketidaksesuaian proses jual beli dengan peraturan yang berlaku. Pengajuan pembatalan akta tersebut kemudian dikabulkan oleh Pengadilan Negeri dengan Putusan Nomor 381/Pdt.G/2014/PN/Bdg. dan Pengadilan Tinggi Bandung dengan Putusan Nomor 451/PDT/2015/PT BDG., sampai akhirnya pembatalan tersebut ditolak dan dibatalkan oleh Mahkamah Agung. Oleh karena itu, penulis ingin mengkaji lebih lanjut mengenai akibat hukum pembatalan akta jual beli (AJB) atas tanah oleh Pejabat Pembuat Akta Tanah (PPAT) dalam Putusan Mahkamah Agung Nomor 888/K/Pdt/2016.

\section{B. Permasalahan}

Berdasarkan latar belakang di atas, penulis merumuskannya menjadi sebuah permasalahan yaitu bagaimana akibat hukum pembatalan akta jual beli (AJB) atas tanah oleh Pejabat Pembuat Akta Tanah (PPAT) dalam Putusan Mahkamah Agung Nomor 888/K/Pdt/2016?

\section{PEMBAHASAN}

\section{A. Jual-Beli Tanah}


Peralihan hak atas tanah bisa terjadi karena pewarisan tanpa wasiat dan perbuatan hukum pemindahan hak. ${ }^{5)}$ Pengertian jual beli tanah menurut Hukum Tanah Nasional adalah pengertian jual beli tanah menurut Hukum Adat. ${ }^{6)}$ Hukum Adat mengatur mengenai jual-beli tanah yang menganut sifat terang dan tunai. Yang dimaksud dengan tunai dan terang adalah bentuk sifat dari jual beli tanah yang digunakan sampai saat ini. Perbuatan jual beli tanah dilakukan pada waktu pemegang haknya masih hidup dan merupakan perbuatan hukum pemindahan hak yang bersifat tunai, kecuali hibah wasiat. Artinya, bahwa dengan dilakukannya perbuatan hukum tersebut, hak atas tanah yang bersangkutan berpindah kepada pihak lain. ${ }^{7)}$ Tunai (contant), juga mempunyai arti harga tanah yang dibayar itu bisa seluruhnya, tetapi bisa juga sebagian. Walaupun dibayar sebagian, menurut hukum telah dibayar penuh. ${ }^{8)}$

Setiap perjanjian yang bermaksud memindahkan hak atas tanah, memberikan sesuatu hak baru atas tanah, menggadaikan tanah atau meminjamkan uang dengan hak atas tanah sebagai tanggungan, harus dibuktikan dengan suatu akta yang dibuat oleh dan di hadapan pejabat yang ditunjuk oleh Menteri Agraria (selanjutnya dalam Peraturan Pemerintah ini disebut sebagai Pejabat). ${ }^{9)}$ Menurut Pasal 1 Angka 1 Peraturan Pemerintah Nomor 24 Tahun 2016 tentang Perubahan Atas Peraturan Pemerintah Nomor 37 Tahun 1998 tentang Peraturan Jabatan Pembuat Akta Tanah, Pejabat Pembuat Akta Tanah, selanjutnya disebut PPAT, adalah pejabat umum yang diberi kewenangan untuk membuat akta-akta otentik mengenai perbuatan hukum tertentu mengenai hak atas tanah atau Hak Milik Atas Satuan Rumah Susun. Akta yang dikenal secara umum terdiri dari akta

\footnotetext{
5) Boedi Harsono, Hukum Agraria Indonesia, Cetakan ke-9, (Jakarta: Djambatan, 2003), hal.333.

6) Adrian Sutedi, Peralihan Hak Atas Tanah dan Pendaftarannya, Cetakan ke-8, (Jakarta: Sinar Grafika, 2017), hal.71.

7) Boedi Harsono, Op.Cit., hal.333.

${ }^{8)}$ Effendi Perangin, Hukum Agraria Indonesia Suatu Telaah dari Sudut Pandang Praktisi Hukum, (Jakarta: Rajawali, 1989), hal.16.

9) A.P Palindungan, Pedoman Pelaksaan UUPA dan Tata Cara Pejabat Pembuat Akta Tanah, Cetakan ke-6, (Bandung: Alumni, 1990), hal.40.
} 
otentik dan akta di bawah tangan. ${ }^{10)}$ Menurut Pasal 1868 KUHPerdata menyebutkan bahwa: "Suatu akta otentik ialah suatu akta yang dibuat dalam bentuk yang ditentukan undang-undang oleh atau dihadapan pejabat umum yang berwenang untuk itu di tempat akta itu dibuat."

Pengertian akta otentik diartikan sebagai akta yang dibuat dalam bentuk yang telah ditentukan oleh undang-undang, dibuat oleh atau di hadapan pegawai umum yang berkuasa untuk itu, ditempat dimana akta dibuatnya. Berdasarkan ketentuan Pasal 15 Ayat (1) Undang-Undang Jabatan Notaris disebutkan bahwa notaris berwenang untuk membuat akta otentik yang dalam pengertian teknis "membuat" atau verlijden adalah melakukan sejumlah pekerjaan yang diperlukan untuk terjadinya akta (notaris). ${ }^{11)}$ Akta otentik telah memenuhi otentisitas suatu akta, ketika telah memenuhi unsurunsur, yaitu: ${ }^{12)}$

a. Akta tersebut dibuat dalam bentuk yang ditentukan oleh UndangUndang;

b. Akta tersebut harus dibuat oleh atau dihadapan seorang pejabat umum;

c. Pejabat Umum itu mempunyai kewenangan untuk membuat akta.

Langkah pertama yang dilakukan dalam kegiatan jual beli tanah adalah mengumpulkan data. Data yang dimaksud adalah data dari para subjek yang ingin melakukan perjanjian, yaitu data penjual dan data pembeli, yang berupa identitas para pihak (Kartu Tanda Penduduk/KTP). Apabila subjek adalah suami-istri maka harus melampirkan Kartu Keluarga (KK). Kemudian data dari objeknya, yang apabila tanah tersebut telah bersertifikat, maka yang perlu dilampirkan adalah sertifikat asli dari tanah tersebut, beserta data-data pendukung, misalnya data mengenai Pajak Bumi dan Bangunan (PBB). Sertifikat tanah wajib hukumnya untuk dicek ke

\footnotetext{
${ }^{10)}$ Sulhan, dkk., Profesi Notaris dan Pejabat Pembuat Akta Tanah, (Jakarta: Mitra Wacana Media, 2018), hal.27.

${ }^{11)}$ Herlien Budiono, Dasar Teknik Pembuatan Akta Notaris, Cetakan ke-2, (Bandung: Citra Aditya Bakti, 2014), hal.7.

${ }^{12)}$ Herlien Soerojo, Kepastian Hukum Hak Atas Tanah Indonesia, (Surabaya: Arkola, 2003), hal.148.
} 
Badan Pertanahan Nasional. Tugas PPAT yang utama dalam prosedur jualbeli tanah adalah:

a. Melakukan pengecekan terhadap sertifikat di Badan Pertanahan Nasional (BPN); dan

b. Membuat akta.

Tugas pendaftaran tanah ada pada BPN dan bukan PPAT. Jika hasil pengecekan dari BPN menyatakan bahwa tanah tersebut tidak dalam keadaan bersih, misalnya tanah tersebut dalam sengketa, tanah tersebut masih ditanggungkan oleh Hak Tanggungan ataupun masih berada di bawah tangan bank, maka akta jual beli tidak dapat dikeluarkan. Tetapi, apabila sertifikatnnya dalam keadaan bersih, maka para pihak dapat datang dan bertemu di kantor PPAT dengan tujuan untuk dibuatnya dan dibacakannya akta serta ditandatangani akta tersebut oleh para pihak, para saksi dan PPAT itu sendiri. Sertifikat asli tersebut kemudian disimpan oleh PPAT dan tidak boleh berada di tangan lain sampai transaksi jual beli tersebut selesai. PPAT wajib membuat lembar satu dan lembar dua, dimana lembar satu untuk PPAT dan lembar dua diberikan kepada BPN untuk disimpan, lalu sisanya yang diberikan kepada para pihak adalah berupa salinan akta. Lembar satu dan lembar dua disebut dengan minuta akta. Ciri fisiknya berupa adanya materai, adanya tanda tangan asli para pihak, para saksi dan PPAT (tanda tangan PPAT berada di tengah), dan adanya cap dari PPAT itu sendiri. Sedangkan salinan akta hanya ada tanda tangan asli PPAT saja tanpa adanya tanda tangan para pihak. Lembar satu yang disimpan PPAT tersebut menjadi bagian dari arsip negara. Minuta akta dan salinan akta adalah akta otentik karena keduanya dibuat di hadapan PPAT sebagai pejabat yang berwenang dan keduanya dianggap sebagai akta yang mempunyai kekuatan pembuktian yang sempuran oleh Hakim di dalam ranah Peradilan.

Mengenai pembatalan akta, dapat dilihat dari syarat sahnya perjanjian yang tercantum dalam 1320 KUHPerdata, yang terdiri dari empat syarat sahnya perjanjian, yaitu:

a. Sepakat mereka yang mengikatkan dirinya 
Orang dikatakan telah memberikan persetujuan/sepakatnya (toestemming), kalau orang memang menghendaki apa yang disepakati. Kalau demikian, sepakat sebenarnya merupakan pertemuan antara kedua kehendak. ${ }^{13)}$ Sepakat tersebut mencakup pengertian tidak saja "sepakat" untuk mengikatkan diri, tetapi juga sepakat untuk mendapatkan prestasi. ${ }^{14)}$

b. Cakap untuk membuat suatu perjanjian

Siapapun yang menurut ketentuan hukum dapat mengemban hak dan kewajiban yang dihasilkan oleh perjanjian, dianggap memliki kewenangan untuk bertindak. Dengan kata lain, setiap subjek hukum yang berwenang dalam melakukan perbuatan hukum berhak menjadi pengemban hak dan kewajiban.

c. Mengenai suatu hal tertentu

Dalam Pasal 1333 KUHPerdata dikatakan, bahwa suatu persetujuan harus mempunyai sebagai pokok benda (zaak) yang paling sedikit ditentukan jenisnya. Objek perjanjian adalah prestasi yang menjadi pokok perjanjian yang bersangkutan. ${ }^{15)}$ Menurut tradisi, untuk sahnya suatu perjanjian, maka objek perjanjian haruslah: ${ }^{16)}$

1) Dapat ditentukan;

2) Dapat diperdagangkan (diperbolehkan);

3) Mungkin dilakukan;

4) Dapat dinilai dengan uang.

d. Suatu sebab yang halal

Suatu kausa atau sebab yang halal berhubungan dengan isi dari perjanjian. Asas kebebasan berkontrak dalam perjanjian dibatasi dengan adanya syarat ini yang mendahulukan kepentingan yang mempunyai hirarki lebih tinggi di masyarakat. Pada umumnya, suatu tindakan

\footnotetext{
${ }^{13)}$ J. Satrio, Hukum Perjanjian, Cetakan ke-4, (Bandung: Citra Aditya Bakti, 1992), hal.128.

${ }^{14)}$ Herlien Budiono, Ajaran Umum Hukum Perjanjian dan Penerapannya di Bidang Kenotariatan, Cetakan ke-4, (Bandung: Citra Aditya Bakti, 2014), hal.73.

15) J. Satrio, Op.Cit., hal.294.

16) Herlien Budiono, Op.Cit., hal.108.
} 
hukum akan dinyatakan dilarang dalam hal perbuatan tersebut bertentangan dengan undang-undang, kesusilaan atau ketertiban umum. 17)

Syarat subjektif terdiri dari dua syarat yang pertama, dikarenan dua syarat pertama tersebut mengenai orang-orangnya atau subyeknya yang mengadakan atau ada di dalam perjanjian, sedangkan dua syarat yang terakhir dinamakan syarat-syarat obyektif karena mengenai perjanjiannya sendiri atau obyek dari perbuatan hukum yang dilakukan itu. Adanya kemungkinan bahwa salah satau atau beberapa syarat tersebut tidak teerpenuhi, maka apabila syarat objektif yang tidak terpenuhi, maka perjanjian itu batal demi hukum. Hal tersebut mempunyai arti bahwa perjanjian tersebut dianggap tidak pernah ada. Akibatnya, perjanjian tersebut tidak dapat digugat kepada Pengadilan (null and void). Apabila syarat subjektif yang tidak dipenuhi, maka salah satu pihak mempunyai hak untuk meminta supaya perjanjian itu dibatalkan. Perjanjian yang demikian dinamakan voidable/vernietigbaar. ${ }^{18)}$

\section{B. Kasus Posisi}

Kasus ini beranjak dari adanya keinginan untuk mengalihkan hak atas tanah atas dua bidang tanah dan bangunan melalui jual beli oleh penjual yang bernama Eva Fatimah dan pembeli yang bernama Yo Swie Tjin dengan akta jual beli yang dikeluarkan oleh seorang Notaris/PPAT (Pejabat Pembuat Akta Tanah) dengan daerah kerja Kota Bandung dan berkantor di Jl. Karawitan No. 93 Bandung, yang bernama Rian Pratama, S.H, M.Kn.

Bermula pada awal bulan Mei 2012, Eva Fatimah meminta staff dari Rian Pratama yang bernama Ibu Gilang untuk datang ke kantornya dengan maksud membuat akta jual beli atas nama Yo Swie Tjin, dan pada saat itu Ibu Gilang bertemu dengan Yo Swie Tjin di kantor developer. Dua hari kemudian staff Eva Fatimah yang bernama Sisi memberikan dua sertifikat asli yaitu Sertifikat Hak Milik (SMH) No.7281 dan Sertifikat Hak Milik

\footnotetext{
17) Ibid., hal.115.

${ }^{18)}$ Subekti, Hukum Perjanjian, (Jakarta: Intermasa, 2002), hal.20.
} 
(SMH) No.7282, dimana kedua akta tersebut atas nama Eva Fatimah, yang kemudian dicek Kantor Pertanahan Kota Bandung, dan setelah dicek, sertifikat asli tersebut dalam keadaan clear tidak ada pembebanan Hak Tanggungan, sitaan atau blokir dari pihak lain, sehingga dapat dibuatkan akta jual beli.

Pada tanggal 8 Mei 2012, Eva Fatimah mengatakan bahwa sertifikat yang dibawa oleh staffnya yang bernama Sisi adalah salah karena sebetulnya kavling yang dibeli Yo Swie Tjin tersebut adalah kaveling A15 dan A16 terdiri dari SHM No.7415 dan SHM No.7416, dimana keduanya terletak di Kelurahan Cisaranten Kulon, atas nama Eva Fatimah. Kemudian, Eva Fatimah meminta staffnya untuk menukar kedua sertifikat asli hak milik yang sebelumnya telah diberikan dengan dua buah fotokopi sertifikat hak milik yang baru dan mengatakan bahwa sertifikat aslinya akan segera disusulkan kepada Rian Pratama, dengan alasan pada saat itu Eva Fatimah baru saja pindah kantor sehingga berkas-berkasnya belum tersusun secara teratur dan ada kemungkinan juga bahwa sertifikat aslinya sedang dalam proses pembetulan di Badan Pertanahan Nasional (BPN).

Pada tanggal 10 Mei 2012, Eva Fatimah kemudian datang bersama dengan Yo Swie Tjin dengan maksud menandatangani akta jual beli di kantor Rian Pratama, dan pada saat pembacaan akta jual beli, Rian Pratama mengatakan kepada para pihak bahwa dua buah sertifikat yang asli belum berada di tangan Rian Pratama dan hanya ada fotokopinya saja. Oleh karena itu, dari proses penandatangan akta jual beli tersebut, Eva Fatimah belum menyerahkan sertifikat asli SHM No.7415 dan SHM No.7416 pada Rian Pratama. Oleh karena itu, Rian Pratama memutuskan baru akan memberikan nomor dan tanggal atas dua draft Akta Jual Beli yang sudah ditandatangani setelah sertifikat asli SHM No.7415 dan SHM No.7416 diserahkan kepadanya.

Pada tanggal 19 Juni 2012, Eva Fatimah meminta Rian Pratama untuk memberikan terlebih dahulu dua salinan akta jual beli atas nama Yo Swie Tjin dengan alasan suami dari Yo Swie Tjin sudah meminta akta-akta 
tersebut. Pada hari yang sama, suami Yo Swie Tjin datang ke kantor Rian Pratama untuk meminta salinan akta jual beli dengan sikap memaksa, sehingga kemudian Rian Pratama menyarankan kepada suami Yo Swie Tjin untuk mengambil salinan akta jual beli di kantor developer.

Setelah suami Yo Swie Tjin pulang dari kantor Rian Pratama, staff Eva Fatimah yang bernama Ibu Tati datang ke kantor Rian Pratama untuk meminta salinan akta jual beli dan mengatakan bahwa Eva Fatimah akan segera menyerahkan sertifikat aslinya kepada Rian Pratama. Setelah melakukan perbincangan, pada tanggal 19 Juni 2012, Rian Pratama mengeluarkan salinan dua buah akta jual beli antara Eva Fatimah selaku penjual dan Yo Swie Tjin selaku pembeli, untuk jual beli tanah dan bangunan yang terletak di Kota Bandung, kecamatan Cisaranten Kulon, Jalan Kampung Cipagalo, setempat dikenal dengan Evergreen Town House Kavling A.15 dan A.16. Akta pertama kemudian diberi nomor 250/2012. Sedangkan, akta kedua diberikan nomor 251/2012. Keduanya dimaksudkan untuk pengalihan hak milik atas tanah dan bangunan berdasarkan Sertifikat hak Milik Nomor 7415 dan Nomor 7416. Pada saat akta jual beli dikeluarkan, kedua sertifikat asli yaitu SHM No.7415 dan SHM No.7416 belum diserahkan ke Penggugat.

Setelah penerbitan salinan akta jual beli tersebut, Yo Swie Tjin dan suaminya sempat datang beberapa kali kepada Rian Pratama untuk menanyakan proses balik namanya. Namun, Rian Pratama mengatakan bahwa sertifikat asli belum diberikan oleh pihak pembeli/developer kepada Rian Pratama. Berdasarkan hal tersebut, Rian Pratama kemudian menyelidiki keberadaan sertifikat tersebut ke Badan Pertanahan Nasional (BPN) dan ternyata setelah dilacak, dua sertifikat tersebut sedang dalam jaminan bank yaitu SHM No. 7415/Cisaranten Kulon ada di Bank Nagari atas nama Andriyati sedangkan SHM No. 7416/ Cisaranten Kulon ada di Bank Mandiri atas nama Andri.

Hal tersebut kemudian menimbulkan konflik karena Rian Pratama merasa telah dirugikan. Rian Pratama berusaha untuk menghubungi para 
pihak namun Eva Fatimah tidak diketahui keberadaannya. Selama mencari penyelesaian atas masalah tersebut, Yo Swie Tjin telah melaporkan adanya dugaan tindak pidana penipuan dan penggelapan oleh Eva Fatimah kepada Kepolisian, yang diproses di Kepolisian Resort Kota Besar Bandung, berdasarkan Laporan Polisi Nomor: LP/1119/V/2013/JBR/Polrestabes. Bdg tanggal 06 Mei 2013. Oleh karena ketidakjelasan keberadaan Eva Fatimah, maka penyelesaian secara musyawarah tidak dapat diselesaikan, serta tidak dapat dihadirkannya SHM asli No.7415 dan SHM No.7416.

Pada tanggal 18 Agustus 2014, Rian Pratama bermaksud untuk membatalkan dua akta jual beli yang dikeluarkannya untuk jual beli antara Eva Fatimah dan Yo Swie Tjin dengan cara mengajukan gugatan kepada Pengadilan Negeri Bandung dengan para pihak sebagai berikut:

1. Rian Pratama, S.H., M.Kn sebagai Penguggat

2. Eva Fatimah sebagai Tergugat I

3. Yo Swie Tjin sebagai Tergugat II

Gugatan Penguggat kemudian dikabulkan oleh Pengadilan Negeri Bandung secara keseluruhan. Oleh karena itu, pada tanggal 5 Juni 2015, Tergugat II mengajukan banding kepada Pengadilan Tinggi Bandung atas putusan Pengadilan Negeri Bandung. Namun, Pengadilan Tinggi Bandung sependapat dengan putusan majelis hakim sebelumnya dan mengabulkan kembali gugatan Penggugat/Terbanding I secara sebagian. Hal tersebut mengakibatkan Tergugat II/Pembanding mengajukan kasasi kepada Mahkamah Agung pada tanggal 10 Desember 2015. Mahkamah Agung membenarkan alasan-alasan kasasi dari Tergugat II/Pembanding/Pemohon Kasasi dan menyatakan bahwa Judex Facti telah membuat kekeliruan dalam menerapkan hukum. Mahkamah Agung kemudian mengabulkan permohonan kasasi dari Tergugat II/Pembanding/Pemohon Kasasi dan menyatakan bahwa gugatan dari Penggugat/Terbanding I/Termohon Kasasi tidak dapat diterima. 


\section{Akibat Hukum Putusan Mahkamah Agung Nomor 888/K/Pdt/2016 Terhadap Akta Jual Beli}

Sebelum melakukan analisis lebih lanjut, perlu diteliti mengenai kesesuaian prosedur jual beli dari kasus terkait dengan ketentuan yang berlaku secara umum. Syarat jual beli dibagi menjadi syarat materiil dan syarat formil. Yang termasuk dalam syarat materiil jual beli tanah terdiri dari:

1. Pembeli berhak membeli tanah yang bersangkutan.

Pembeli dalam kasus ini berhak dalam membeli dua bidang tanah yang dijual dengan hak milik. Dalam kasus ini, pembeli telah memenuhi persyaratan tersebut.

2. Penjual berhak menjual tanah yang bersangkutan.

Seharusnya penjual adalah pemilik tanah. Namun, dalam kasus ini, penjual sesungguhnya telah menimbulkan suatu kebingungan dan keraguan dalam menjual dua bidang tanah tersebut. Hal tersebut terjadi karena pada awalnya sertifikat hak milik tersebut diberikan, kedua sertifikat tersebut ada di bawah nama penjual, namun pada saat dicek kedua sertifikat hak atas tanah asli yang ada disimpan oleh bank, keduanya ada di bawah nama orang lain dan bukan Eva Fatimah selaku penjual. Dua sertifikat tersebut sedang dalam jaminan bank yaitu SHM No. 7415/Cisaranten Kulon ada di Bank Nagari atas nama Andriyati sedangkan SHM No. 7416/ Cisaranten Kulon ada di Bank Mandiri atas nama Andri.

3. Tanah hak yang bersangkutan boleh diperjualbelikan.

Di dalam hukum tanah nasional, objek hak atas tanah yang dapat diperjualbelikan adalah tanah dengan hak milik, hak guna usaha, hak guna bangunan dan hak pakai. Tanah yang bersangkutan sesungguhnya boleh untuk diperjualbelikan karena hak atas tanah tersebut berupa hak milik. Dalam hal ini, tanah tersebut dimaksudkan untuk dialihkan melalui jual beli melalui akta jual beli.

4. Tanah hak yang bersangkutan tidak sedang dalam sengketa. 
Dua bidang tanah yang menjadi objek jual-beli adalah dalam keadaan clear dari sengketa, dan menjadi objek jaminan bank tidaklah termasuk ke dalam kategori dalam sengketa. Hal tersebut telah dibuktikan dengan telah adanya pengecekan yang dilakukan oleh PPAT terhadap tanah tersebut, yang kemudian didukung dengan fakta bahwa sertifikat hak milik dua bidang tanah tersebut telah diterima untuk dijadikan objek jaminan oleh bank, sehingga dapat ditarik suatu pernyataan bahwa bank juga telah melakukan pengecekan terlebih dahulu.

Apabila dilihat dari keterangan tersebut, dapat kemudian dikatakan bahwa jual-beli tanah tersebut sesungguhnya tidak dapat dilaksanakan karena adanya salah satu syarat materiil yang tidak dipenuhi. Syarat yang tidak dipenuhi adalah syarat subjektif, artinya syarat-syarat yang berhubungan dengan subjek hukum yang melakukan kegiatan jual beli tanah. Namun fakta mengenai sertifikat hak milik bukan atas nama Penjual/Tergugat I tersebut memang baru kemudian diketahui setelah salinan akta jual beli diterbitkan.

Selain syarat materiil, perlu juga diperhatikan syarat formil dari jual beli tanah, yaitu secara singkat, jika tanah yang diperjualbelikan telah memiliki sertifikat, maka perlu disertakan sertifikat tanahnya yang asli dan tanda bukti pembayaran biaya pendaftarannya. Dalam kasus ini, jual beli tanah yang terkait tidak memenuhi syarat formil, dikarenakan sertifikat asli tidak berada di tangan penjual, pembeli maupun PPAT pada saat jual beli dilaksanakan dan pada saat penerbitan salinan akta jual beli. Dalam kasus ini, fakta tersebut telah diberitahukan kepada seluruh pihak tetapi kegiatan jual beli tetap dilaksanakan tanpa adanya pemenuhan terhadap syarat formil maupun syarat materiil jual beli tanah.

Sesungguhnya penerbitan akta jual beli tersebut juga melanggar Pasal 39 Ayat (1) huruf a Peraturan Pemerintah Nomor 24 Tahun 1997 tentang Pendaftaran Tanah, yang berbunyi:

PPAT menolak untuk membuat akta, jika mengenai bidang tanah yang sudah terdaftar atau hak milik atas satuan rumah susun, kepadanya tidak disampaikan sertifikat asli hak yang bersangkutan atau sertifikat yang 
diserahkan tidak sesuai dengan daftar-daftar yang ada di Kantor Pertanahan.

Sertifikat asli sudah seharusnya diserahkan kepada PPAT dan tetap harus ada di bawah tangan PPAT tersebut dan tidak boleh berpindah tangan ke pihak lain sampai proses transaksi jual beli tanah selesai. Sehingga akta jual beli yang dikeluarkan oleh Penggugat tidak sesuai dengan Standard Operating Procedure (SOP) baik dalam praktik maupun peraturan perundang-undangan.

Kemudian dikeluarkanlah Putusan Mahkamah Agung yang membatalkan Putusan Pengadilan Tinggi yang mengabulkan gugatan Penggugat, dimana Mahkamah Agung dengan jelas menyatakan pertimbangannya atas putusannya tersebut berupa pihak yang terdapat dalam suatu perjanjian adalah pihak yang berhak untuk membatalkan perjanjian yang bersangkutan. PPAT bukanlah pihak yang termasuk ke dalam perjanjian tersebut dan mengutip dari pertimbangan Majelis Hakim Mahkamah Agung, bahwa PPAT tidak mempunyai kepentingan ekonomi dari perjanjian tersebut, sehingga PPAT dianggap bukanlah pihak yang bersangkutan dalam perjanjian yang dituangkan dalam bentuk akta jual beli tersebut. PPAT kemudian dianggap tidak mempunyai legal standing dalam mengajukan gugatan tersebut sehingga gugatan dinyatakan tidak dapat diterima.

Terkait dengan kasus yang dibahas, dapat dikatakan bahwa putusan Pengadilan Negeri dan Pengadilan Tinggi yang menyatakan bahwa akta jual beli tersebut cacat hukum sudah benar menurut penulis, karena terdapat beberapa syarat baik dalam segi materiil maupun segi formil jual beli tanah yang gagal dipenuhi oleh pihak-pihak yang bersangkutan, khususnya pihak penjual, yaitu Tergugat I dalam perbuatan jual beli tanah. Oleh karena itu, menurut Penulis, pernyataan cacat hukum merupakan ungkapan yang tepat dalam menjatuhkan putusan terhadap kedua akta jual beli tersebut jika dikaitkan dengan ketidaksesuaian prosedur dalam pembuatan akta jual beli yang bersangkutan. Hal tersebut juga kemudian mengakibatkan bahwa akta 
jual beli tersebut tidak mengikat secara hukum dengan tujuan agar tidak merugikan para pihak.

Namun, dalam kasus ini, terdapat suatu kekeliruan dalam pengajuan gugatan pembatalan akta, dimana yang mengajukan adalah pihak PPAT sendiri. Dalam hakikatnya, pembatalan suatu akta hanya dapat dilaksanakan para pihak yang bersangkutan dan ada di dalam perjanjian dan/atau para pihak yang mempunyai kepentingan hukum. Oleh karena itu, berdasarkan putusan Mahkamah Agung tersebut, akta jual beli yang sebelumnya mempunyai status cacat hukum, dibatalkan statusnya tersebut dan kembali kepada keadaan semula, yaitu sebelum gugatan tersebut dibuat oleh Penggugat. Artinya, bahwa akta jual beli dianggap kembali berlaku serta mempunyai kekuatan hukum yang mengikat karena salinan akta jual beli termasuk ke dalam bentuk akta otentik. Peralihan hak atas tanah kemudian dapat dikatakan tetap berlansung. Hal ini kemudian menjadi sebuah permasalahan karena akta jual beli tersebut dikeluarkan dengan prosedur yang memiliki ketidaksesuaian dengan hukum positif yang ada. Hal ini juga kemudian akan berdampak kepada proses pembalikan nama di Badan Pertanahan Nasional nantinya, dimana tanpa sertifikat hak milik asli, proses tersebut tidak dapat terlaksana. Proses pendaftaran yang salah juga mengakibatkan akta tersebut mempunyai kepastian hukum yang lemah.

Berdasarkan hal tersebut, akta jual beli dapat kemudian diajukan pembatalan tetapi oleh para pihak, khususnya pihak yang mengalami kerugian. Artinya, pihak yang merasa dirugikan diperkenankan untuk mengusulkan suatu opsi yaitu membatalkan akta. Namun, perlu diperhatikan bahwa semua pihak yang ada di perjanjian harus setuju atas pembatalan tersebut. Merujuk pada Pasal 1338 KUHPer, yang berbunyi: "Persetujuan itu tidak dapat ditarik kembali selain dengan kesepakatan kedua belah pihak, atau karena alasan-alasan yang ditentukan oleh undang- undang." Oleh karena itu, dapat ditarik sebuat pernyataan bahwa pembatalan tersebut dapat dilaksanakan apabila para pihak dalam perjanjian sepakat untuk melakukan pembatalan akta tersebut. 
Alasan pembatalan lain yang dapat digunakan adalah adanya unsur penipuan yang diakui oleh Pembeli/Tergugat I. Penipuan terletak pada waktu menandatangani perjanjian bersama Pembeli/Tergugat II dihadapan PPAT/Penggugat, ketika itu Pembeli/Tergugat I menyatakan bahwa sertifikat asli ada dan belum diserahkan karena terselip sehubungan kepindahan kantornya dan arsip surat-surat belum tersusun, namun ternyata kedua sertifikat tersebut sudah dijadikan jaminan ke Bank Nagari dan Bank Mandiri. Hal tersebut kemudian diakui oleh Penjual/Tergugat I sendiri. Maka pembatalan akta tersebut dapat dilaksanakan dengan mengacu pada Pasal 1328 KUHPer, dimana penipuan dikategorikan sebagai cacat dalam kehendak.

Selain itu, dengan dikeluarkannya Peraturan Menteri Negeri Agraria/Kepala Badan Pertanahan Nasional Nomor 11 Tahun 2016 tentang Penyelesaian Kasus Pertanahan, adanya jalan alternatif mengenai penyelesaian sengketa akta jual beli tersebut berupa pengaduan yang dapat diajukan oleh para pihak kepada Kepala Kantor Pertanahan. Pengaduan dapat disampaikan baik secara tertulis melalui loket pengaduan Kepala Kantor Pertanaha., maupun melalui website Kementrian. Pengaduan tersebut minimal memuat identitas pengadu dan kasus posisi secara singkat. Hal tersebut diatur di dalam Pasal 6 dan Pasal 7 Peraturan Menteri Negeri Agraria/Kepala Badan Pertanahan Nasional Nomor 11 Tahun 2016 tentang Penyelesaian Kasus Pertanahan. Penyelesaian sengketa tersebut, menurut Pasal 37 Peraturan Menteri Negeri Agraria/Kepala Badan Pertanahan Nasional Nomor 11 Tahun 2016 tentang Penyelesaian Kasus Pertanahan, dapat dilakukan melalui mediasi.

D. Akibat Hukum Putusan Mahkamah Agung Nomor 888/K/Pdt/2016 Terhadap Pejabat Pembuat Akta Tanah (PPAT)

PPAT adalah seorang pejabat umum yang mempunyai kewenangan untuk membuat akta otentik yang berhubungan suatu bidang tanah tertentu dan perbuatan hukum yang dilakukan terhadap tanah tersebut. Dalam Pasal 2 Peraturan Pemerintah Nomor 37 Tahun 1998 tentang Peraturan Jabatan 
Pembuat Akta Tanah, jual-beli merupakan salah satu perbuatan hukum yang dimaksud yang menjadi kewenangan PPAT. Fungsi dari akta PPAT yang dibuat adalah sebagai alat bukti telah terjadinya perbuatan hukum tersebut. ${ }^{19)}$ Sehingga dalam pembuatannya, PPAT dituntut untuk dapat mengerjakan tugasnya dengan berpedoman pada ketentuan yang berlaku, beritikad baik dan menjunjung tinggi profesionalisme.

Jika dikaitkan dengan fakta-fakta yang terdapat di dalam kasus dalam putusan Mahkamah Agung Nomor 888/K/Pdt/2016 dengan peran serta tugas PPAT dalam pembuatan suatu akta jual beli, dapat dijabarkan menjadi sebagai berikut:

1. Dari proses penandatangan akta jual beli tersebut, Eva Fatimah belum menyerahkan sertifikat asli SHM No.7415 dan SHM No.7416 pada Rian Pratama. Pada tanggal 19 Juni 2012, Rian Pratama mengeluarkan salinan dua buah akta jual beli antara Eva Fatimah selaku penjual dan Yo Swie Tjin selaku pembeli. Pada saat akta jual beli dikeluarkan, kedua sertifikat asli yaitu SHM No.7415 dan SHM No.7416 belum diserahkan ke Penggugat. Hal ini merupakan suatu pelanggaran terhadap Pasal 39 Ayat (1) huruf a Peraturan Pemerintah Nomor 24 Tahun 1997 tentang Pendaftaran Tanah, yang berbunyi:

PPAT menolak untuk membuat akta, jika mengenai bidang tanah yang sudah terdaftar atau hak milik atas satuan rumah susun, kepadanya tidak disampaikan sertifikat asli hak yang bersangkutan atau sertifikat yang diserahkan tidak sesuai dengan daftar-daftar yang ada di Kantor Pertanahan.

2. Setelah penerbitan dua salinan akta jual beli, Rian Pratama baru kemudian menyelidiki keberadaan sertifikat tersebut ke Badan Pertanahan Nasional (BPN) dan ternyata setelah dilacak, dua sertifikat tersebut sedang dalam jaminan bank yaitu SHM No. 7415/Cisaranten Kulon ada di Bank Nagari atas nama Andriyati sedangkan SHM No. 7416/ Cisaranten Kulon ada di Bank Mandiri atas nama Andri. Hal tersebut kemudian melanggar Dalam Pasal 97 Peraturan Menteri Negeri

\footnotetext{
${ }^{19)}$ Boedi Harsono, Op.Cit., hal. 518.
} 
Agraria/Kepala Badan Pertanahan Nasional Nomor 3 Tahun 1997 tentang Ketentuan Pelaksaan Peraturan Pemerintah Nomor 24 Tahun 1997 tentang Pendaftaran Tanah, yang menyatakan bahwa:

Sebelum melaksanakan pembuatan akta mengenai pemindahan atau pembebanan hak atas tanah atau Hak Milik Atas Satuan Rumah Susun, PPAT wajib terlebih dahulu melakukan pemeriksaan pada Kantor Pertanahan mengenai kesesuaian sertipikat hak atas tanah atau Hak Milik Atas Satuan Rumah Susun yang bersangkutan dengan daftar-daftar yang ada di Kantor Pertanahan setempat dengan memperlihatkan sertipikat asli.

Berdasarkan fakta-fakta di atas, dapat ditarik suatu pernyataan bahwa dalam prosedur pembuatan akta-jual beli, Rian Pratama selaku PPAT telah melakukan beberapa kelalaian yaitu menerbitkan salinan akta jual beli tanpa menyimpang sertifikat hak milik asli dari kedua bidang tanah yang diperjual belikan dan tidak melakukan pemeriksaan terhadap kedua bidang tanah tersebut sebelum menerbitkan salinan akta jual beli. Hal tersebut kemudian menjadi konflik karena sertifikat hak milik asli kedua bidang tanah tersebut sedang menjadi objek jaminan di bank.

Di dalam ketiga putusan oleh tiga tingkat pengadilan tersebut, tidak dibahas mengenai perbuatan PPAT tersebut, namun jika dilihat dari beberapa poin yang telah dipaparkan sebelumnya, maka PPAT tersebut dapat dikatakan telah melakukan suatu kesalahan dimana pihak dalam perjanjian sesungguhnya dapat menuntut PPAT tersebut akibat dikeluarkannya akta jual beli yang mempunyai potensi besar untuk membawa kerugian terhadap para pihak kecuali apabila para pihak membatalkan perjanjian tersebut. PPAT kemudian wajib mengganti rugi kerugian tersebut apabila gugatan para pihak dikabulkan oleh Pengadilan sebagai akibat dari dikeluarkannya akta.

Selain ganti rugi, sanksi lain yang dapat diterima oleh PPAT sebagai akibat hukum dari perbuatan penerbitan akta tersebut adalah sanksi administrasi dan sanksi kode etik. Menurut penulis, di dalam Kode Etik PPAT Pasal 3 huruf p dinyatakan bahwa PPAT harus melakukan perbuatan- 
perbuatan lain yang secara umum disebut sebagai kewajiban untuk ditaati dan dilaksanakan antara lain: ketentuan perundang-undangan lainnya yang terkait dengan kewajiban PPAT. Oleh karena itu, penulis berpendapat bahwa karena PPAT sudah melanggar PP Nomor 24/1997 yang memuat kewajiban PPAT dalam hal pendaftaran tanah, maka PPATtersebut telah juga melanggar kode etik PPAT.

Jika ditinjau dari PP Nomor 24/1997, maka sanksi dari pelanggaran terhadap Pasal 39 tersebut dinyatakan dalam Pasal 62, yang menyatakan:
PPAT yang dalam melaksanakan tugasnya mengabaikan ketentuan-ketentuan sebagaimana dimaksud dalam Pasal 38, Pasal 39 dan Pasal 40 serta ketentuan dan petunjuk yang diberikan oleh Menteri atau Pejabat yang ditunjuk dikenakan tindakan administratif berupa teguran tertulis sampai pemberhentian dari jabatannya sebagai PPAT, dengan tidak mengurangi kemungkinan dituntut ganti kerugian oleh pihak- pihak yang menderita kerugian yang diakibatkan oleh diabaikannya ketentuan-ketentuan tersebut.

PPAT dapat dikenai sanksi berupa pemberhentian sementara sampai kepada pemberhentian tetap. Mengenai pelanggaran dan pemberhentian tersebut akan diperiksa lebih lanjut oleh Majelis Pengawas Daerah (MPD) yang akan menyelenggarakan sebuah sidang untuk memeriksa perkara mengenai kelalaian PPAT tersebut. Sehingga, para pihak dapat juga melaporkan PPAT kepada MPD terlebih dahulu selain mengajukan gugatan ke Pengadilan. Pemberhentian secara sementara sendiri pun ditetapkan oleh Kepala Badan Pertanahan Nasional Republik Indonesia.

\section{PENUTUP}

\section{A. Kesimpulan}

Berdasarkan keterangan-keterangan di atas, dapat ditarik suatu kesimpulan bahwa akibat hukum terhadap akta jual beli dalam kasus yang menjadi pembahasan penulis adalah akta jual beli tersebut dapat dibatalkan dengan ketentuan bahwa hanya pihak yang terikat dalam perjanjian yang dapat membatalkan akta tersebut serta semua pihak dalam perjanjian, dalam 
hal ini penjual dan pembeli, harus sepakat untuk membatalkan akta. Perbedaan dari ketiga putusan Pengadilan Negeri, Pengadilan Tinggi dan Mahkamah Agung terletak pada adanya kekeliruan dalam menentukan siapa yang berwenang dalam dalam mengajukan pembatalan tersebut. Namun selain hal tersebut, perlu juga diperhatikan bahwa adanya ketidaksesuaian proses dalam penerbitan akta jual beli dengan ketentuan-ketentuan yang berlaku. Dapat kemudian ditarik suatu kesimpulan bahwa akibat hukum terhadap PPAT dalam kasus yang menjadi pembahasan penulis adalah PPAT dapat dikenai sanksi administratif berupa pemberhentian secara sementara maupun secara tetap, dan juga PPAT diharuskan untuk membayar ganti rugi yang mungkin diderita oleh para pihak yang merasa dirugikan oleh perbuatan yang dilakukan PPAT tersebut, yaitu penerbitan salinan akta jual beli.

\section{B. Saran}

Berdasarkan kasus ini, dapat kemudian menjadi himbauan kepada PPAT untuk menghindari penerbitan akta yang belum memenuhi syarat-syarat jual-beli tanah secara seksama dan teliti. Juga menjadi sebuah peringatan kepada PPAT untuk selalu melakukan pengecekan terhadap data-data yang menjadi dasar pembuatan akta jual beli tersebut secara teliti dan benar. Untuk perihal kelalaian PPAT, dengan tujuan mencegah terjadinya hal demikian kembali, memang diperlukan suatu pengawasan terhadap PPAT. Sesungguhnya, hukum positif telah mengatur mengenai ketentuan pengawasan dan pembinaan pejabat umum khususnya PPAT, namun dalam pelaksanaannya masih banyaknya kelalaian yang dilakukan di masayarakat. Hal tersebut dapat merugikan orang-orang yang membutuhkan bantuan pejabat umum, sehingga perlunya lebih ditegakkan pembinaan serta pengawasan terhadap kerja PPAT di lapangan untuk menghindari hal-hal seperti yang terjadi dalam kasus yang dibahas penulis. Masih banyaknya PPAT yang lolos dari sanksi juga merupakan dorongan bagi para PPAT untuk melakukan kelalaian baik dalam porsi kecil maupun porsi besar. Selain itu, para PPAT juga harus menjunjung tinggi jabatannya dan juga 
kode etik PPAT agar selalu menjadikan peraturan perundang-undangan yang berlkau sebagai dasar dalam menjalankan tugasnya sehingga tidak menimbulkan konflik ataupun kerugian bagi dirinya sendiri maupun para pihak yang bersangkutan.

\section{DAFTAR PUSTAKA}

\section{A. Buku}

Budiono, Herlien. Dasar Teknik Pembuatan Akta Notaris. Cetakan ke-2. (Bandung: Citra Aditya Bakti, 2014).

Kumpulan Tulisan Hukum Perdata di Bidang Kenotariatan Buku Kesatu. Cetakan Ke-4. (Bandung: Citra Aditya Bakti, 2016).

Ajaran Umum Hukum Perjanjian dan Penerapannya di Bidang Kenotariatan. Cetakan ke-4. (Bandung: Citra Aditya Bakti, 2014).

Fuady, Munir. Konsep Hukum Perdata. Cetakan ke-2. (Jakarta: Rajawali Pers, 2015).

Harsono, Boedi. Hukum Agraria Indonesia. Cetakan Ke-9. (Jakarta: Djambatan, 2003).

Kansil, C.S.T. Pengantar Ilmu Hukum dan Tata Hukum Indonesia. (Jakarta: Balai Pustaka, 2002).

Oryza, Dyara Radhite. Panduan Mengurus Tanah Rumah dan Perizinannya. (Yogyakarta: Legality, 2018).

Palindungan, A.P. Pedoman Pelaksaan UUPA dan Tata Cara Pejabat Pembuat Akta Tanah. Cetakan ke-6. (Bandung: Alumni, 1990).

Perangin, Effendi. Hukum Agraria Indonesia Suatu Telaah dari Sudut Pandang Praktisi Hukum. (Jakarta: Rajawali, 1989).

Santoso, Urip. Hukum Agraria Kajian Komprehensif. (Jakarta: Kencana Prenada Media Group, 2012). 
- Pendaftaran dan Peralihan Hak Atas Tanah.

Cetakan ke-9. (Jakarta: Kencana Prenada Media Group, 2013).

Satrio, J. Hukum Perjanjian. Cetakan ke-4. (Bandung: Citra Aditya Bakti, 1992).

Sutedi, Adrian. Peralihan Hak Atas Tanah dan Pendaftarannya. Cetakan ke-8. (Jakarta: Sinar Grafika, 2017).

Soerojo, Herlien. Kepastian Hukum Hak Atas Tanah Indonesia. (Surabaya: Arkola, 2003).

Sulhan, dkk. Profesi Notaris dan Pejabat Pembuat Akta Tanah. (Jakarta: Mitra Wacana Media, 2018). 